on contracts could begin as soon as titles had been selected. A Publishing Trade Consultative Panel had been set up after consultation with the trade organizations concerned. The British Council was steadily expanding its own library services and co-operating with Colonial Governments in improving their services and there had boen consultation with trade organizations in the periodical field on measures to assist circulation of newspapers and periodicals in some of the more difficult markets overseas. Consultation was also taking place with the publishing trade in Great Britain and other countries with the view of encouraging more effective wholesaling and retailing of books in the African countries in particular. Answering a further question, about documentary films, Dr. Hill said that in 1958-59 the Central Office of Information commissioned twentyeight documentary films and acquired 118, all for overseas distribution, and in 1959-60 it was expected that about 120 would be acquired. More than a hundred British films had been entered in 1959 for showing at international festivals and twenty-one awards or special mentions had been gained.

National Lending Library for Science and Technology: Consultative Committee

A consultative Committee has been appointed to advise the Department of Scientific and Industrial Research on the services of the National Lending Library for Science and Technology. Literature is now being collected for the Library by the Lending Library Unit of the Department at 20 Chester Terrace, Regent's Park, London, N.W.I. The National Lending Library for Science and Technology will be located near Boston Spa, Yorkshire, and its transfer will take place in the first half of 1961. Its collection of scientific literature, which will become the largest in the United Kingdom, will be available to any organizations through loan and photocopying services.

The Committee is as follows: Sir Lindor Brown, biological secretary of the Royal Society (chairman); Prof. J. D. Bernal, professor of physies, Birkbeck College, London; Mr. D. I. Colley, librarian, Manchester Public Library ; Dr. B. M. Crowther, editor of Science Abstracts; Mr. G. H. Davison, secretary of the United Steel Companies, Ltd., Research Department ; Dr. R. E. Fairbairn, head of the Library Department, I.C.I. Dyestuffs Division, and chairman of the Council of Aslib; Mr. R. M. Fishenden, United Kingdom Atomic Energy Research Estab. lishment, Harwell; Prof. G. Gee, Sir Samuel Hall professor of chemistry, University of Manchester ; Mr. C. W. Hanson, research officer, Aslib; Mr. L. J. H. Haylor, Ministry of Supply; Mr. K. W. Humphreys, librarian, University of Birmingham, and secretary of the Standing Conference of National and University Libraries; Mr. D. D. Morgan, information manager, P.E.R.A. ; Prof. W. J. T. Morgan, Lister Institute of Preventive Medicine, London; Mr. H. T. Pledge, keeper, Science Museum; Dr. M. R. Pollock, Medical Research Council; Mr. A. C. Townsend, library of the British Museum (Natural History). The secretary of the Committee is Miss R. M. Bunn.

\section{Dounreay Fast Breeder Reactor Critical}

The Fast Breeder Reactor at Dounreay went critical on November 14. The reactor will go through a period of low-power operation for some months. This may be followed by a shut-down for any modifications found necessary, and the reactor will then be worked up to power in stages. Construetion work on this reactor started in May 1955 and it was scheduled to start operating last year. Because of the redeployment of staff due to the Windscale pile incident and to certain design modifications, start-up has been delayed. The reactor consists of a central core which is a hexagonal prism approximately 21 in. high and $21 \mathrm{in}$. across the flats. This is made up of about 360 enriched uranium rods in niobium cans, and is surrounded by a 'blanket' of 2,000 rods of natural uranium which under irradiation produces plutonium. Plutonium can be used in the core to produce more heat and more plutonium, and experiments have shown that the amount of fissile material produced in the core and the blanket during operation will exceed the amount burned up in the core, and the reactor is thus a breeder. In this type of reactor the neutrons are not deliberately slowed down as in a thermal reactor, that is, no 'moderator' is used and the neutrons are said to be 'fast'. Heat is removed from the core and blanket by a liquid sodium-potassium alloy, which is circulated by electromagnetic pumps through the vessel and through heat exchangers. The reactor with its primary heat exchanger circuits is installed in a concrete vault within the $135-\mathrm{ft}$. diameter steel sphere which dominates the Dounreay site. In the early stages the Dounreay reactor will be operated to provide information on the physics and control characteristies of this type of systern, and this will be followed by a stage of intensive development and testing of different types of fuel elements.

\section{South African Council for Scientific and Industrial Research}

THE thirteenth annual report of the South African Council for Scientific and Industrial Research covers the year ended March 31, 1958, and includes lists of research bursaries and assistantships awarded during the year as well as a list of publications (Pp. xvii + $226+x i x-$ lix. Pretoria: South African Council for Scientific and Industrial Research, 1958). Concern is expressed as to the shortage of scientists and particularly at the loss overseas of promising South African scientists. Much interest is being taken in the work on the demineralization of water by electrodialysis, and the plant designed by the Council and being erected at Welkom has a capacity of $2 \cdot 5$ million gallons a day. River surveys involved a comprehensive programme of chemical, biological, bacteriological tests and flow data, as well as laboratory studies on the chemical and biological reactions in water and river mud. A Wine Research Unit was established at Stellenboseh, where it is hoped that investigations of the causes of biotic turbidity will offer a solution of a serious problom in South African wines. Investigations on the chemical mechanism of carcinogenesis continued. Initial difficulties with the cyclotron at the National Physical Laboratory were overcome during the year and improvements in several of the basic components increased the stability of operation. The isotope separator was assembled in December 1957, and the electro-mechanical recording systems in South African Courts established by the Acoustics Division were further extended. Under a recently established Foundry Sands fellowship the properties of available sands are being studied and their suitability for easting determined. At the National Mechanical Engineering Research Institute 